\title{
Arms Race Between Turkey and Greece: Time-Varying Causality Analysis
}

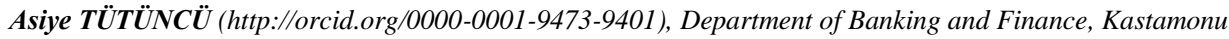 \\ University, Turkey; e-mail: ttncasiye@gmail.com
}

Burak ŞAHINGÖZ (https://orcid.org/0000-0002-4179-1609), Department of Public Finance, Karadeniz Technical University, Turkey; e-mail: buraksahingoz@windowslive.com

\section{Türkiye ve Yunanistan Arasındaki Silahlanma Yarışı: Zamanla Değişen Nedensellik Analizi}

\begin{abstract}
An arms race is the dynamic process followed by states in the acquisition of weapons. An arms race requires mutual military expenditures during this process to support the arms race hypothesis among states. This study elaborated on the arms race hypothesis between Turkey and Greece for the period 1960-2016 with the help of time-varying causality testing as well as bootstrap causality testing and asymmetric causality testing. The bootstrap causality test results proved that there is a unidirectional causality relation between Greece's defense expenditures and Turkey's defense expenditures, whereas the asymmetric causality testing results proved that a mutual relationship exists between the two states' defense expenditures. Further, according to the time-varying causality testing results, the presence of an arms race can be confirmed between the two countries for the periods 19751990 and 2000-2014.

Keywords

JEL Classification Codes : $\mathrm{H} 56, \mathrm{C} 22$.

Arms Race, Military Expenditures, Asymmetric Causality, TimeVarying Causality.

\section{$\ddot{O} z$}

Silahlanma yarışı, ülkelerin silah edinimi konusunda yaşadıkları dinamik süreci ifade etmektedir. Ülkeler arasında silahlanma yarışı hipotezinin geçerli olabilmesi için bu süreçte askeri harcamaların karşılıklı etkileşimi gerekmektedir. Bu çalışmada Türkiye ile Yunanistan arasındaki silahlanma yarışı hipotezi, 1960-2016 dönemi Hacker ve Hatemi-J (2006) bootstrap nedensellik ve Hatemi-J (2012) asimetrik nedensellik testlerinin yanı sıra zamanla değişen nedensellik testi yardımıyla incelenmiştir. Hacker ve Hatemi-J (2006) bootstrap nedensellik testi sonuçları, Yunanistan'ın savunma harcamalarından Türkiye'nin savunma harcamalarına tek yönlü nedensellik ilişkisi olduğunu, asimetrik nedensellik testi ise iki ülkenin savunma harcamaları arasında saklı ilişki olduğunu göstermektedir. Zamanla değişen nedensellik testi sonuçlarına göre 1975-1990 ve 20002014 dönemlerinde iki ülke arasında silahlanma yarışının geçerli olduğu tespit edilmiştir.
\end{abstract}

Anahtar Sözcükler : : Silahlanma Yarışı, Savunma Harcamaları, Asimetrik Nedensellik, Zamanla Değişen Nedensellik. 


\section{Introduction}

Nowadays, there are many problems that governments must solve. In general, these problems are to increase economic development and prosperity, provide adequate education, health and infrastructure services and ensure national security. These basic services must be provided to meet the demand. Therefore, the services to be provided should be made within the framework of a specific program and in accordance with the needs.

However, it is not always possible to set a specific framework for providing services such as national security. The reason for this is not only internal factors but also external factors. These factors can be briefly stated as international wars, civil wars, external threats, change in defense expenditures of neighboring and competing countries (arms race), change in population and internal threats. When threat risks increase, countries will increase defense spending and will have to waive other services that they need to provide.

One of the reasons that increase the defense expenditures of the countries is the arms race. An arms race is defined as a dynamic process and competitive environment for the acquisition of weapons between two states or interstate unions (e.g., Eastern Bloc-Western Bloc; Intriligator \& Brito: 2000: 46). In this process, it is assumed that the military expenditures of the involved countries will increase as they try to build more powerful military forces and acquire more weapons.

Arms races cannot always change the mutual balance of power of states because each state or bloc invests heavily in defense systems. For instance, Turkey to purchase advanced military aircraft or development of nuclear bombs may provoke the same reaction from Greece. At the end of the process, the balance of power protects their conditions and does not change. Additionally, a formidable process that irresistibly worsens the economic situation of states occurs (Harari, 2015: 210).

Figure 1 demonstrates arms races between states. It is assumed that an arms race has existed between two states since 2000. The vertical axis shows the defense expenditures of $\mathrm{A}$ and $\mathrm{B}$ countries. The defense expenditures have a share in the capital budget, as shown in the figure, and the part above the defense expenditures represents other expenditures in the capital budget. Defense expenditures are not meant only for arms races but also refer to other elements such as international wars, civil wars, external threats, changes in neighboring or opponent countries, population exchanges, and internal threats (Collier \& Hoeffler, 2002: 4). Therefore, defense expenditures did not start over from scratch in 1993. Figure 1 shows that the defense expenditures and, accordingly, their share in the government budget increased since 2000 when the arms race began. By 2016, the two countries started to invest significantly more in defense. Throughout this dynamic process, the balance of power did 
not experience any changes because both countries increased their defense expenditure mutually. However, defense expenditures had a significant share in the government budget ${ }^{1}$.

Figure: 1

\section{Arms Race}

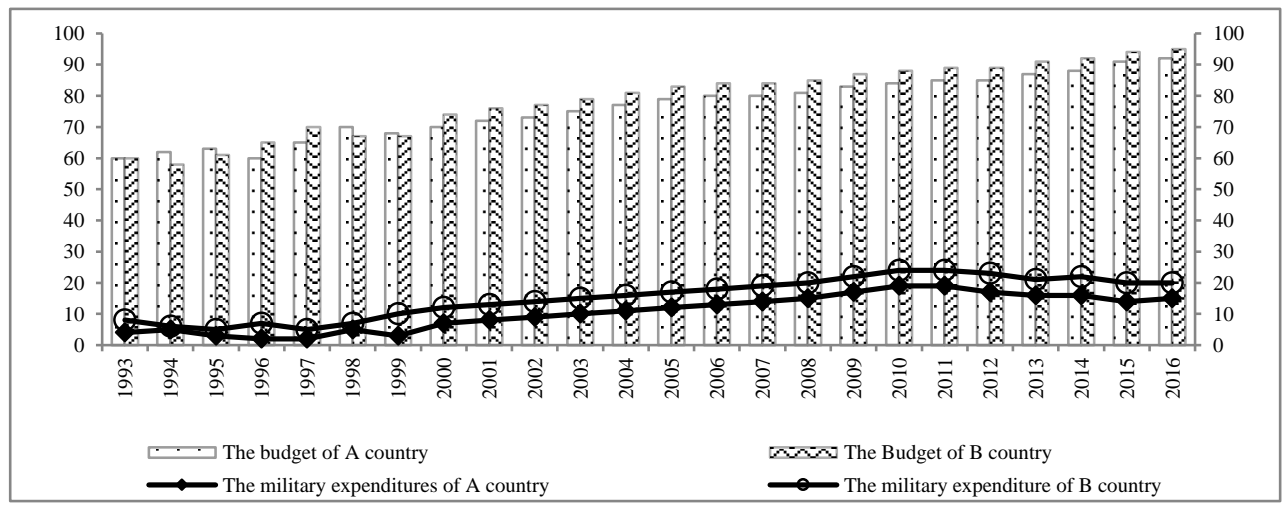

Source: Hypothetically created by authors.

The validity of the arms race hypothesis has been tested in various studies on blocs that pose a threat to each other (Pakistan and India, Russia and the United States, Arab countries and Israel). Turkey and Greece are seen as a threat risk for each other because of historical problems between the two countries. Tension between the two countries started in the 1950s and increased gradually in the 1960s. Issues related to Cyprus led to the current problems between Turkey and Greece. This issue started in 1955 and reached a peak in 1974 as a result of Turkey's interference in Cyprus. The armament of the Aegean Islands by Greece in 1964 brought a new issue into the agenda. Greece officially informed to the International Civil Aviation Organization in 1974 that it extended its national air space to 10 miles. Turkey defends six miles of territorial waters in the Aegean whereas Greece alleged that she has the right to extend it to 12 miles depending on the 1982 Convention on the Law of the Sea. Turkey called this a Casus Belli. In 1999, the capture of Abdullah Öcalan in the Greek Embassy in Kenya increased tensions again between the two countries. Though reconciliation policies were on the agenda between the two countries after 1990, perceptions of threat could not be eradicated because of the Öcalan issue and the unsolved Cyprus and Aegean Islands issues. Between 1999 and 2016, the ratio of two countries' defense expenditures to GDP has been above the average for NATO member states and the fact that

1 One country may bear arms to increase security, and another country may do the same. Therefore, when a country is armed, whatever the reason for this may be, it can cause other countries to become armed as well. This situation, which is called a security dilemma, can create an arms race that causes the situation of countries to get worse (Jervis, 1978). 
both countries are among the top 10 countries in the world with the most armaments is a suspicious indicator ${ }^{2}$.

The aim of the study is to investigate whether the arms race that increases defense spending between Greece and Turkey. In the literature, the question that is "Is there an arms race between the two countries?" has been answered with various econometric analyzes. The results show that there is no consensus. In this study, with the difference of the literature, the arms race between the two countries is analyzed with time varying causality test. Timevarying causality test can be applied to measure the time-varying effect of the relationship between variables. Thanks to this test, it can be explained arms race, and if there are arms race, which periods it belongs. It has never seen using time varying causality in the literature examining the arms race between Turkey and Greece.

\section{Literature Review}

The aforementioned issues between Turkey and Greece brought an arms race onto the agenda for both countries. The first study that tested the arms race hypothesis mathematically was conducted by Richardson (1960), but the pioneering study on the Turkish-Greek arms race hypothesis was by Majeski and Jones (1981).

Majeski and Jones (1981) criticized the restrictive Richardson model and defended the use of causality analysis to eliminate the restrictive model for better testing. Bidirectional causality, unidirectional causality, and no causality can be determined through causality testing. The absence of a causality relation cannot support the arms race hypothesis, and it also brings into question the validity of the arms race hypothesis when the findings of unidirectional causality relation are reached. Unidirectional relation is described as a reaction to a rival country's current or former military expenditure. This situation is defined as the race of a country (Majeski \& Jones, 1981: 280). Therefore, both countries must react to the military expenditure of the rival country to prove the arms race hypothesis, and the causality relation must be bidirectional (Brauer, 2002: 122; Georgiou, 1996: 236; Kollias \& Markrydakis, 1997: 362).

It is possible to divide the Turkey and Greece arms race literature into three categories: studies that reject the arms race hypothesis, those that partially support the hypothesis, and those that support the hypothesis. Georgiou (1990), Georgiou et al. (1996), and Paparas et al. (2016) found a unidirectional causality relation between Greece and Turkey in their causality tests, whereas Smith et al. (2000) benefited from game theory and

2 Turkey is ranked eighth among the states spending the most money on armaments in the world, with \$14.6 billion in expenditures, whereas Greece is ninth, with \$13.1 billion, for the 1999-2016 period (Stockholm International Peace Research Institute [SIPRI]). The ratio of the defense expenditure to GDP among NATO member countries in accounted for 1,7\% between 1999 and 2016. This ratios for Turkey and Greece were 2,5\% and 2,7\% respectively (World Development Indicators). 
Hamilton's regime-switching model. Two situations were created according to the prisoner's dilemma (Greece leads and Turkey follows in the first situation, and Turkey leads and Greece follows in the second situation), but the hypothesis was rejected in the two situations. Sahin and Ozsoy (2008) used Markov's switching model and did not find meaningful statistical proof between the two countries in relation to the arms race. Further, Öcal and Yildirim (2009) used the TAR and M-TAR cointegration models to investigate the possibility of an asymmetric error correction for the long-run equilibrium. They found that Turkish military expenditures harmonized with long-run deviations, whereas Greek military expenditures failed to do so. Among the studies that partially support the arms race between the two countries, Kollias (1991) and Dunne et al. (2005) applied the Richardson model to test the arms race hypothesis for Turkey and Greece but could not reach meaningful findings to prove the validity of the hypothesis. The studies that found bidirectional causality relation between two countries according to the causality rest results are among the top studies that accepted the arms race hypothesis between Turkey and Greece (Kollias \& Markrydakis, 1997; Kollias \& Paleologou, 2002; Majeski \& Jones, 1981; Majeski, 1985). Among the studies that accepted the validity of the hypothesis, Öcal (2002) considered the hypothesis based on the impact of countries' military expenditures mutually by using STR and LSTR models. According to the results, the change in Turkey's military expenditures affects the military expenditures of Greece. According to the LSTR model results, Greece does not want to fall behind in military expenditures compared to Turkey. Andreou and Zombanakis (2011) divided their research into two sub-periods-before 2000 and after 2000-and examined the arms race between Turkey and Greece using the artificial neural networks (ANN) method. The study revealed that the arms race continued after 2000 and that the tension between the countries remained high.

The literature shows that there is no consensus on whether the arms race was valid. Following Brauer's (2002: 90-91) statement-which implies that even if there was a race, it ended in the period 1985-90-the questions "Did the arms race between Turkey and Greece end?" and "Is there an arms race between Turkey and Greece?" arise in the literature. These questions have formed the basis of many studies (Andreou \& Zombanakis, 2011: 4; Dunne et al., 2005: 210; Öcal \& Yıldırım, 2009: 124; Sahin \& Ozsoy, 2008: 4). Andreou and Zombanakis (2011: 4) in particular criticized Brauer's (2002) statements for not reflecting the real political and strategic environment in the region and stated that the arms race between the two countries continued after 2000. Within the scope of our study, regarding this contradictory situation, the answers to the two aforementioned questions we considered the answers to the help of causality tests.

The political and military history of the countries and the existing agreements between them affects the extent of the arms race. For this reason, the asymmetric structure between countries is important and needs to be tested. In the studies conducted, the existence of the arms race between the two countries have been tested with the traditional causality tests, but no common conviction has been reached. In this study, three different causality tests have been used and the results have been discussed in it. For this purpose, Hatem-J (2012) asymmetric causality test and time-varying causality test have been used in addition to Hacker and Hatemi-J (2006) bootstrap causality test. 


\section{Methodology}

We applied the augmented Dickey-Fuller (ADF), Phillips and Perron (PP, 1988), and Lee and Strazicich (LS, 2003) unit roots tests, which allow for two structural breaks to determine the stationarity level of variables. Because the Dickey-Fuller (DF) unit root test is criticized for being insufficient to overcome autocorrelation problem in error terms, an attempt is made to overcome the problem by adding the lags of the dependent variable to the equations in Dickey and Fuller's (1981) study. Phillips and Perron (1988) proposed a new approach consisting of modified $t$ values and allowing heterogeneous distribution of error terms in contrast to weakly dependent and ADF unit root tests.

In the case of structural breaks in a series, conventional unit root tests may result in unit rooted in stationary series. Thus, we used the LS (2003) unit root test, which allowed for structural breaks, to examine the unit root process of variables. This test was developed under the assumption that the ADF type structural break unit root tests tendency to reject the null hypothesis of the unit root existence, leading to the deterioration of the dimensional feature. We used the LS unit root test in the Lagrange multiplier (LM) type test strategy allowing double breaks during the development process.

The Hacker-Hatemi-J bootstrap causality test used in the study is based on Toda and Yamamato's (1995) causality test, which in turn was based on the Granger causality test. Toda and Yamamoto (1995) criticize the loss of information caused by taking differences of the variables in the Granger causality test. The Toda and Yamamoto's causality test is based on the $\operatorname{VAR}\left(k+d_{\max }\right)$ model, which allows variables to be included in level values in the model are developed to prevent this situation. The modified WALD test (MWALD), which has $\chi^{2}$ distribution in the VAR model and has normal distribution of error terms, is used by adding optimal lag length $(k)$ as well as maximum stationary rank $\left(d_{\max }\right)$. Hacker and Hatemi-J (2006) examined the size characteristics of MWALD test statistics using Monte Carlo simulations. Their findings showed deteriorations in MWALD test statistics, especially for small samples. Moreover, it is not possible for every case where the error term of the variables has a normal distribution. Hacker and Hatemi-J (2006: 1492) stated that MWALD test statistics tend to reject the $H_{0}$ hypothesis, which asserts no causality relation between variables. This may lead to a failure to capture correct dimension features in finite samples and to misleading results. The use of the bootstrap method, which was developed by Efron (1979), allows one to overcome this deterioration in MWALD test statistics.

Causality tests developed in the literature are based on the assumption that the effects of variables' cumulative positive and negative shocks are the same. It was first suggested by Granger and Yoon (2002) that the impact of these shocks on variables may be different. Granger and Yoon tested the cointegration relation among variables by dividing variables into cumulative positive and negative shocks. Hatemi-J (2012) used cumulative positive and negative shocks for causality and thus examined the asymmetric causality relation. We used equations (1) and (2) to search the causality relation in $y_{1 t}$ and $y_{2 t}$ variables.

$$
y_{1 t}=y_{1 t-1}+\varepsilon_{1 t}=y_{10}+\sum_{i=1}^{t} \varepsilon_{1 i}
$$




$$
y_{2 t}=y_{2 t-1}+\varepsilon_{2 t}=y_{20}+\sum_{i=1}^{t} \varepsilon_{2 i}
$$

$t=1,2, \ldots, T$ and $y_{1,0}$ ve $y_{2,0}$ in equations (1) and (2) represent the initial value. Positive shocks are shown in equation (3), and negative shocks are shown in equation (4).

$$
\begin{aligned}
& \varepsilon_{1 i}^{+}=\max \left(\varepsilon_{1 i}, 0\right) \text { ve } \varepsilon_{2 i}^{+}=\max \left(\varepsilon_{2 i}, 0\right) \\
& \varepsilon_{1 i}^{-}=\max \left(\varepsilon_{1 i}, 0\right) \text { ve } \varepsilon_{2 i}^{-}=\max \left(\varepsilon_{2 i}, 0\right) \\
& \varepsilon_{1 i}=\varepsilon_{1 i}^{+}+\varepsilon_{1 i}^{-} \text {ve } \varepsilon_{2 i}=\varepsilon_{2 i}^{+}+\varepsilon_{2 i}^{-} . \text {In this case, using equations (1) and (2), the }
\end{aligned}
$$
causality relation between variables can be examined, and it can be expressed in equations (5) and (6) as follows by rearranging equations (1) and (2):

$$
\begin{aligned}
& y_{1 t}=y_{1 t-1}+\varepsilon_{1 t}=y_{1,0}+\sum_{i=1}^{t} \varepsilon_{1 i}^{+}+\sum_{i=1}^{t} \varepsilon_{1 i}^{-} \\
& y_{2 t}=y_{2 t-1}+\varepsilon_{2 t}=y_{2,0}+\sum_{i=1}^{t} \varepsilon_{2 i}^{+}+\sum_{i=1}^{t} \varepsilon_{2 i}^{-}
\end{aligned}
$$

Positive and negative shocks for each variable are cumulatively calculated as follow:

$$
\begin{aligned}
& y_{1 t}^{+}=\sum_{i=1}^{t} \varepsilon_{1 i}^{+}, y_{1 t}^{-}=\sum_{i=1}^{t} \varepsilon_{1 i}^{-} \\
& y_{2 t}^{+}=\sum_{i=1}^{t} \varepsilon_{2 i}^{+}, y_{2 t}^{-}=\sum_{i=1}^{t} \varepsilon_{2 i}^{-}
\end{aligned}
$$

Therefore, assuming that $y_{t}^{+}=\left(y_{1 t}^{+}, y_{2 t}^{+}\right)$, the asymmetric relation between variables is tested with the help of equation (9).

$$
y_{t}^{+}=v+Z_{1} y_{1-1}^{+}+\cdots+Z_{p} y_{t-1}^{+}+u_{t}^{+}
$$

In Hatemi-J's (2012) study, Hacker and Hatemi-J's (2006) test, which was based on Toda and Yamamoto's (1995) causality test, allows the investigation of asymmetric causality by including causality shocks in the bootstrap causality test. Hacker and Hatemi-J (2006) bootstrap causality test is applied to variables that are divided as cumulative positive and negative shocks.

It is common to use fixed-window-sized rolling forecasters in the time series under the presence of parameter instability to measure the time-varying effect. Sub-samples are created at the window size as determined from the beginning of the data set in this method. The number of sub-samples is calculated from the difference $(m-l)$ between the data set length $(m)$ and window size $(l)$. Thus, it allows the change of causality results over time by applying bootstrap causality test based on the VAR model for each window length.

There is no certain criterion in choosing window size. The choice of optimal window size must be calculated by considering two different views. First, the estimate of degree of freedom must be large enough to predict the parameters, and second, multiple structural change potential must consist of small sub-samples that will decrease the window size and risk of multiple breaks (Balcilar et al., 2010: 1403). 


\section{Data Set and Empirical Analysis Results}

Our study focuses on the military expenditures of Turkey and Greece in relation to an arms race between the two countries. We examine the 1960-2016 period using Hacker and Hatemi-J's (2006) bootstrap and Hatemi-J's (2012) asymmetric and time-varying causality tests. The share of military expenditures of the national income is examined using data obtained from the World Bank. The maximum causality level of variables must be determined through the methods used in the study. We applied the LS unit root test, which allows two structural breaks, as well as ADF and PP traditional unit root tests, to a series. Table 1 presents the results of the traditional unit root tests, whereas Table 2 presents the LS unit root test results.

Table: 1

ADF and PP Unit Root Tests Results

\begin{tabular}{|c|c|c|c|c|}
\hline & \multicolumn{2}{|c|}{ ADF Unit Root Tests } & \multicolumn{2}{c|}{ PP Unit Root Tests } \\
\hline & C & C+T & C & $-2,243$ \\
\hline TME & $-1,413$ & $-2,278$ & $-1,320$ & $-8,916^{* * * *}$ \\
\hline TME & $-7,979^{* * *}$ & $-7,986^{* * *}$ & $-7,986^{* * *}$ & $-2,139$ \\
\hline GME & $-1,551$ & $-1,959$ & $-1,724$ & $-6,306^{* * *}$ \\
\hline$\Delta$ GME & $-6,288^{* * *}$ & $-6,269^{* * *}$ & $-6,286^{* * *}$ & \\
\hline
\end{tabular}

Notes: ${ }^{* * *}$ means a level of significance of $1 \%$.

In addition to $\mathrm{ADF}$ and $\mathrm{PP}$ unit root tests, the LS unit root test results prove that both variables are stationary at the I(1) level. Thus, it is confirmed that the maximum stationarity level is I(1) for causality tests based on Toda and Yamamoto (1995) causality tests.

Table: 2

\section{LS Unit Root Tests}

\begin{tabular}{|c|c|c|c|c|}
\hline & Model A & Breaks Date & Model C & Breaks Date \\
\hline TME & $-3,119$ & $1970-2003$ & $-5,089$ & $1973-2005$ \\
\hline$\Delta$ TME & $-8,217^{* * *}$ & $1983-2002$ & $-9,782^{* * *}$ & $1972-1975$ \\
\hline GME & $-3,654$ & $1973-1985$ & $-5,269$ & $1975-1985$ \\
\hline$\Delta$ GME & $-6,857^{* * *}$ & $1965-1973$ & $-7,546^{* * *}$ & $1968-1974$ \\
\hline
\end{tabular}

Notes: ${ }^{* * *}$ means a level of significance of $1 \%$.

For the discussed model, The ARCH effect developed by Hacker and Hatemi-J (2005) and the Multivariate Normality Test developed by Doornik and Hansen (1994) were applied to the model. Findings show that the ARCH effect is present in the model and that the VAR model is not normally distributed ${ }^{3}$. For this reason, the bootstrap techniques have been applied while testing out the arms race between Greece and Turkey. Furthermore, the lag length of the VAR model was determined by means of the lag length criteria suggested by Hatemi-J (2003). Our results of Hacker and Hatemi-J's (2006) bootstrap causality test (Table 3) demonstrate that the direction of causality is from Greece's military expenditures 
to Turkey's military expenditures. This proves that Turkey is affected by the military expenditures in Greece. This is not surprising, especially for Turkey, because of the uncertainty in the southern region. However, the bidirectional causality relation must be between countries to confirm the validity of the arms race. In this case, according to the results obtained from Hacker and Hatemi-J's (2006) bootstrap causality test, we cannot be certain about the arms race between the countries.

Table: 3

\section{Bootstrap Causality Results}

\begin{tabular}{|c|c|c|}
\hline Model & $\mathrm{TME}=\mathrm{f}(\mathrm{GME})$ & $\mathrm{GME}=\mathrm{F}(\mathrm{TME})$ \\
\hline Test Statistics & $13,972^{* * *}$ & 0,309 \\
\hline Notes: ${ }^{* * * *}$ means a level of significance of $1 \%$. Bootstrapped distribution is obtained with 10,000 replications for
\end{tabular}
the critical values.

Causality tests in the literature are based on the assumption that variables react the same to positive and negative shocks. Granger and Yoon (2002) showed a hidden cointegration relation between variables as a result of the cointegration analysis conducted by separating cumulative positive and negative shocks of variables. Hatemi-J (2012) also applied Granger and Yoon's (2002) study to a causality test and reached the conclusion that the hidden relation is valid for causality tests. In current study, we applied an asymmetric causality test that was examined by Hatemi-J (2012) to variables separated in cumulative negative and positive shocks, and the findings are demonstrated in Table 4.

Table: 4

Asymmetric Causality Test Results

\begin{tabular}{|c|c|c|}
\hline & GME = F(TME) & TME $=\mathrm{f}(\mathrm{GME})$ \\
\hline $\mathrm{X}+$ to Y+ & 0,961 & $27,45^{* * *}$ \\
\hline X- to Y- & $7,292^{* * *}$ & 0,369 \\
\hline
\end{tabular}

Notes: *** means a level of significance of 1\%. Bootstrapped distribution is obtained with 10,000 replications for the critical values.

According to the causality tests, a hidden causality relation can be seen in one of the shocks when the relation between variables is calculated. Regarding negative shocks, the direction of the relation is from Turkey's military expenditures to Greece's military expenditures; Regarding positive shocks, the direction is reversed. The military expenditures of countries affect each other's because of the bidirectional relation that emerges when negative and positive shocks are considered together. In that case, the arms race hypothesis between Turkey and Greece is valid.

Time-varying causality test results of the measurement of the time-varying effect between variables are shown in Figure 2. Further, we used 10,000 bootstrap values with the help of the Schwarz Information Criteria (SIC) criterion with a maximum length of 3 lag for this test, as in other methods. The level of significance is set at $10 \%$.

For the period 1960-2016 in the current study, 42 sub-samples were analyzed using 15 years as the fixed window size for the period 1960-2016. We applied Hacker and HatemiJ's (2006) bootstrap causality test to each sub-sample to obtain time-varying causality test 
results for these sub-samples. The results of the countries' causalities must be below the significance level in the same period to prove the validity of the arms race hypothesis. When Figure 2 is examined, in addition to the 15th and 16th periods for the countries, the causality relation in the 40th period is found to be under the $10 \%$ significance level. These periods represent the years 1975-1990 and 2000-2014. According to the results of the time-varying causality test, the periods for which the arms race is confirmed represent periods when many countries had political and military tensions.

\section{Figure: 2}

\section{Time-Varying Causality Result}

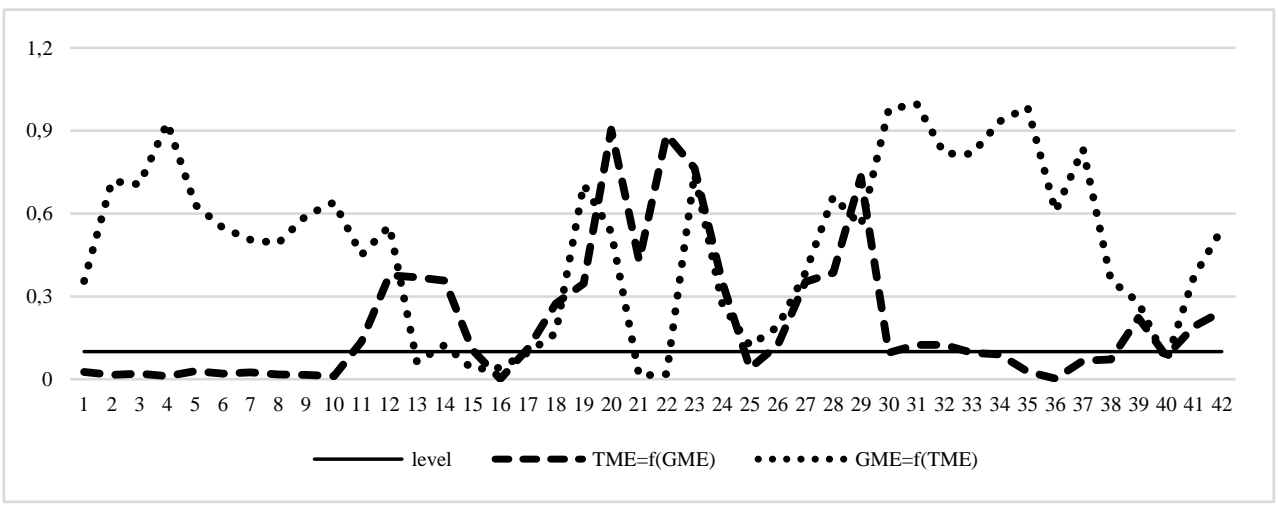

\section{Conclusion}

In the current study, we tested the arms race hypothesis between Turkey and Greece using Hacker and Hatemi-J's (2006) and Hatemi-J's (2012) time-varying tests for the 19602016 periods. Hacker and Hatemi-J's (2006) bootstrap causality test results demonstrated that the arms race hypothesis among the two countries is not valid. However, based on the asymmetric causality test results, we determined that the relation between variables is hidden, and therefore the hypothesis is valid. Because the causality tests provided different results, we applied the time-varying causality test. According to the findings of this test, arms races between Turkey and Greece in the sub-periods of 1975-1990 and 2000-2014 were detected.

The arms race in the period 1975-1990 was supported statistically with empirical results at the 5\% level of significance. In 1974, the tension between Turkey and Greece, caused by Turkey's Cyprus peace operation, increased, and both country started an arms race the following year. Subsequently, the peaceful environment in the 1990s was affected by the capture of Abdullah Öcalan, who was involved in terrorist activities in Turkey, in a Greek embassy. This again led to an increase in the tension between the two countries again. However, in the period after the 1990s, especially after 2000, there have been significant breakthroughs in political consensus that have decreased the potential threat perception between the two countries. Therefore, the arms race hypothesis in Turkey and Greece in the 
period 2000-2014 is statistically at a lower significance level compared to the period 19751990.

The extant literature does not offer common answers for the questions "Did the arms race between Turkey and Greece end?" and "Is there an arms race between Turkey and Greece?" The findings from the current study support the idea that the arms race between the two countries ended during the period 1985-1990, as stated by Brauer (2002), and that it continued after 2000, as stated by Andreou and Zombanakis (2011). The current study showed that although the arms race between the two countries was said to have ended after 2000, it continued during the period 2000-2014. These findings indicate that the arms race has ended, but they do not give information about whether it might recur. However, given the current issues between the countries of Turkey and Greece and their sensitive political relations, any increase in tensions between the two may expose the existence of the arms race.

On the other hand, the arms race between the two countries causes an increase in defense expenditures. This situation causes that resources is used from fields such as education, health, infrastructure, economic growth and development to be transferred to defense expenditures. According to the results of the research findings, the arms race is not a continuous phenomenon. The implementation of reconciliatory policies can reduce the tension between the two countries. In this way, reconciliatory policies in the political field will help to use resources more effectively.

\section{References}

Andreou, A.S. \& G.A. Zombanakis (2011), "Financial versus Human Resources in The GreekTurkish Arms Race 10 Years on: A Forecasting Investigation Using Artificial Neural Networks", Defence and Peace Economics, 22(4), 459-469.

Balcilar, M. \& Z.A. Ozdemir \& Y. Arslanturk (2010), "Economic Growth and Energy Consumption Causal Nexus Viewed through a Bootstrap Rolling Window", Energy Economics, 32, 1398-1410.

Brauer, J. (2002), "Survey and Review of the Defense Economics Literature on Greece and Turkey: What have We Learned?", Defence and Peace Economics, 13(2), 85-107.

Collier, P. \& A. Hoeffler (2002), "Military Expenditure: Threats, Aid, and Arms Races", World Bank Policy Research Working Paper No. 2927, 1-23.

Dickey, D.A. \& W.A. Fuller (1981), "Likelihood Ratio Statistics for Autoregressive Time Series with a Unit Root", Econometrica, 49(4), 1057- 1072.

Dunne, J.P. \& N. Eftychia \& R.P. Smith (2005), "Is there an Arms Race between Greece and Turkey?", Peace Economics, Peace Science and Public Policy, 11(2), 1-35.

Georgiou, G. (1990), "Is There an Arms Race Between Greece and Turkey? Some Preliminary Econometric Results", Cyprus Journal of Economics, 3(1), 58-73.

Georgiou, G.M. \& P.T. Kapopoulos \& S. Lazaretou (1996), "Modelling Greek-Turkish Rivalry: An Empirical Investigation of Defence Spending Dynamics", Journal of Peace Research, 33(2), 229-239. 
Granger, C.W.J. \& G. Yoon (2002), “Hidden Cointegration”, University of California Economics Working Paper No. 2002-02.

Hacker, R.S. \& A. Hatemi-J (2006), "Tests for Causality between Integrated Variables Using Asymptotic and Bootstrap Distributions: Theory and Application", Applied Economics, 38(13), 1489-1500.

Harari, Y.N. (2015), Sapiens: A Brief History of Humankind, New York: Harper Collins.

Hatemi-J, A. (2012), “Asymmetric Causality Tests with an Application”, Empirical Economy, 43, 447-456.

Hiro Y.T. \& Y. Taku (1995), "Statistical Inference in Vector Autoregressions with Possibly Integrated Processes", Journal of Econometrics, 66, 225-250.

Intriligator, M.D. \& D.L. Brito (2000), “Arms Race”, Defence and Peace Economics, 11(1), 45-54.

Jervis, R. (1978), “Cooperation Under the Security Dilemma”, World Politics, 30(2), 167-214.

Kollias, C. \& S. Makrydakis (1997), "Is There a Greek-Turkish Arms Race?: Evidence from Cointegration and Causality Tests", Defence and Peace Economics, 8(4), 355-379.

Kollias, C. \& S. Paleologou (2002), "Is There a Greek-Turkish Arms Race? Some Further Empirical Results from Causality Tests", Defence and Peace Economics, 13(4), 321-328.

Kollias, C. (1991), "Greece and Turkey: The Case Study of an Arms Race from The Greek Perspective", SPOUDAI-Journal of Economics and Business, 41(1), 64-81.

Lee, J. \& M.C. Strazicich (2003), "Minimum Lagrange Multiplier Unit Root Test with Two Structural Breaks", The Review of Economics and Statistics, 85(4), 1082-1089.

Majeski, S.J. \& D. Jones (1981), “Arms Race Modeling: Causality Analysis and Model Specification”, The Journal of Conflict Resolution, 25(2), 259-288.

Majeski, S.J. (1985), “Expectations and Arms Races”, American Journal of Political Science, 29(2), 217-245.

Öcal, N. \& J. Y1ldırım (2009), “Arms Race between Turkey and Greece: A Threshold Cointegration Analysis", Defence and Peace Economics, 20(2), 123-129.

Öcal, N. (2002), "Asymmetric Effects of Military Expenditure between Turkey and Greece", Defence and Peace Economics, 13(5), 405-416.

Paparas, D. \& C. Richter \& A. Paparas (2016), "Military Spending and Economic Growth in Greece and the Arms Race between Greece and Turkey", Journal of Economics Library, 3(1), $38-56$.

Phillips, P.C.B. \& P. Perron (1988), “Testing for a Unit Root in Time Series Regression”, Biometrika, 75(2), 335-346.

Richardson, L.F. (1960), Arms and Insecurity: A Mathematical Study of Causes and Origins of War, Pittsburgh: Boxwood Press.

Sahin, H. \& O. Ozsoy (2008), “Arms Race between Greece and Turkey: A Markov Switching Approach", Defence and Peace Economics, 19(3), 209-216.

Smith, R. \& M. Sola \& F. Spagnola (2000), "The Prisoner's Dilemma and Regime-Switching in the Greek-Turkish Arms Race”, Journal of Peace Research, 37(6), 737-750. 